\author{
dr Dorota WYSZKOWSKA \\ Wydział Ekonomii i Zarządzania, Uniwersytet w Białymstoku \\ e-mail: d.wyszkowska@uwb.edu.pl
}

DOI: $10.15290 /$ oes.2018.01.91.09

\title{
SAMORZĄD TERYTORIALNY W UJĘCIU WYBRANYCH KONCEPCJI TEORETYCZNYCH
}

\begin{abstract}
Streszczenie
Samorząd terytorialny jest trwałym elementem współczesnych państw demokratycznych. Jego powołanie uzasadniane jest efektywniejszą od scentralizowanej, dostawą dóbr i usług publicznych. Zasadność przeprowadzenia procesów decentralizacji terytorialnej i powołania samorządu terytorialnego można odnaleźć w różnych koncepcjach teoretycznych, wśród których szczególne miejsce zajmuje teoria federalizmu fiskalnego.

W artykule podjęto problem teoretycznego uzasadnienia powołania samorządu terytorialnego i przyznania mu samodzielności. Artykuł ma charakter teoretyczny i poglądowy.

Realizacja przyjętego celu wymagała zastosowania metody typowej dla nauk społecznych - analizy literatury. Przeprowadzone badania literaturowe pozwoliły na wskazanie roli samorządu terytorialnego w realizacji zadań publicznych oraz zasadności przyznania mu samodzielności w ujęciu koncepcji teoretycznych.

W artykule przeanalizowano wybrane celowo koncepcje teoretyczne odnoszące się do znaczenia samorządu terytorialnego, a mianowicie: teorię federalizmu fiskalnego, teorię wyboru publicznego oraz teorię lokalizmu.
\end{abstract}

Słowa kluczowe: samorząd terytorialny, samodzielność, teoria federalizmu fiskalnego, teoria wyboru publicznego, teoria lokalizmu

\section{SELF-GOVERNMENT IN A SELECTED THEORETICAL CONCEPT}

\section{Summary}

Local government is a permanent element of modern democratic countries. This appointment is justified by a more effective than centralized delivery of public goods and services. The legitimacy of the processes of territorial decentralization and the establishment of local self-government can be found in various theoretical concepts, among which the theory of fiscal federalism has a special place.

The article addresses the problem of a theoretical approach justifying the establishment of local government and granting it autonomy. The article is theoretical and comparative.

The implementation of the adopted objective required the use of a method typical for social sciences - literature analysis. The literature research allowed to indicate the role of territorial selfgovernment in the implementation of public tasks and the legitimacy of granting it autonomy in terms of theoretical concepts.

The article analyzes the theoretically selected theoretical concepts referring to the importance of territorial self-government, namely: the theory of fiscal federalism, the theory of public choice, and the theory of localism. 
Key words: self-government, autonomy, Fiscal Federalism, Public Choice, the theory of localism

JEL classification: H10, H21, H71

\section{Wstęp}

Samorząd terytorialny stanowi nieodzowny element współczesnych demokratycznych państw. Jego istnienie jest instytucjonalną formą organizowania się działających na ich terytorium społeczeństw. To w znacznej mierze dzięki niemu dokonuje się uspołecznianie władzy publicznej i upodmiotowienie tych społeczeństw. Bez samorządu terytorialnego demokratyczne państwo prawa byłoby wysoce upośledzone, a wręcz przypisanie takiego charakteru państwu byłby problematyczne [Faliński, 2014, s. 70; Wnuk-Lipiński, 2008, s. 117-139]. Za powołaniem samorządu terytorialnego przemawia efektywniejsza realizacja zadań publicznych w zdecentralizowanym systemie zarządzania państwem.

Samorząd terytorialny powstał jako efekt decentralizacji władzy i przejawia się przeniesieniem na szczebel samorządowy zarówno zadań administracji publicznej, jak i środków finansowych na ich realizację. U podstaw powoływania współczesnego samorządu leży przypisanie jednostkom samorządu terytorialnego samodzielności w różnych aspektach. Pratchett traktuje samodzielność w sposób wielopłaszczyznowy, uznając, że jest to: po pierwsze, wolność jednostek terytorialnych od ingerencji władzy centralnej (freedom from central interference), po drugie, swoboda decyzyjna tych jednostek w zakresie realizacji określonych celów/rezultatów (freedom to effect particular outcomes), a po trzecie, odzwierciedlenie tożsamości lokalnej (reflection of local identity), [Pratchett, 2004, s. 358]. Samodzielność można rozpatrywać w ujęciu: prawnym, kompetencyjnym lub zadaniowo-kompetencyjnym, organizacyjnym, finansowym, socjologicznym, politycznym [Filipiak, Dylewski, 2016, s. 341]. W literaturze przedmiotu podkreśla się, że prawdziwa samodzielność samorządu terytorialnego nie może istnieć bez jej wymiaru finansowego (samodzielności finansowej) [Onofrei, 2007, s. 75], któremu poświęca się wiele uwagi w teorii federalizmu fiskalnego. Jest to teoria w najpełniejszy i najszerszy sposób odnosząca się do wielopoziomowego zarządzania państwem, stąd została jako pierwsza zaprezentowana w opracowaniu.

W literaturze dotyczącej funkcjonowania samorządu terytorialnego wiele miejsca poświęca się dyskusji na temat zasadności jego powoływania, znaczenia, różnych aspektów samodzielności oraz optymalnej wielkości jednostek samorządu terytorialnego (JST), zapewniającej efektywność ekonomiczną ich działania. Argumentów przemawiających za przypisaniem silnej roli samorządowi terytorialnemu pojawiło się wiele na gruncie teorii dotyczących trzech wartości, a mianowicie: wzrostu efektywności alokacji zasobów, wzmocnieniu partycypacji politycznej oraz ochrony praw obywatelskich [Bukowska 2008, s. 47]. We współczesnej teorii ekonomii można wyróżnić trzy zasadnicze koncepcje odnoszące się do roli i zakresu kompetencji samorządu terytorialnego [Por. Kozuń-Cieślak 2009, s. 242-248]. Wśród nich na szczególną uwagę zasługuje wspomniana już teoria federalizmu fiskalnego - 
Fiscal Federalizm (R. A. Musgrave, P. B. Musgrave), teoria wyboru publicznego Public Choise [Wilkin, 2005, s. 13] ${ }^{1}$ (J. M. Buchanan, G. Tullock, A. Downs) oraz teoria lokalizmu - the theory of localism (J. Stewart i G. Jones) [Jones, Stewart 1983, Stych 2013, s. 46]. Stąd też to one zostaną zaprezentowane w niniejszym opracowaniu.

Za powoływaniem samorządu terytorialnego byli przedstawiciele różnych szkół ekonomicznych (np. szkoły sztokholmskiej, czy austriackiej). Na przykład Fridrich von Hayek (przedstawiciel szkoły austriackiej), podobnie jak Alexis de Tocqueville, zwracał uwagę na niebezpieczeństwo centralizacji władzy. Jako Lord Acton powiedział słynne słowa „Cała władza korumpuje; władza absolutna korumpuje absolutnie" [Hartwich]. Elementy przemawiające za tworzeniem i przypisaniem istotnej roli w świadczeniu usług publicznych, jak też swobody działania JST można odnaleźć także w koncepcji nowego zarządzania publicznego - New Public Management (E. Ferlie, L. Ashburner, L. Fitzgerald oraz A. Pettigrew), jak też koncepcji współrządzenia publicznego - Public Governance [por. Beer-Tóth, s. 11-25], czy też nowej ekonomii instytucjonalnej - New Instytutianal Economy (T. Veblen, W. C. Mitchell oraz J. R. Commons) [szerzej: Kozuń-Cieślak, 2009]. Teorie te nie będą przedmiotem dalszej analizy.

Celem artykułu jest dokonanie przeglądu trzech wybranych koncepcji teoretycznych w kontekście przekazania JST zadań publicznych do realizacji oraz przyznania im samodzielności w różnych aspektach działania. Ich wybór podyktowany był tym, że w największym stopniu odnoszą się one do tematyki podjętej w niniejszym opracowaniu. Podstawą dwóch pierwszych z nich jest krytyka mechanizmów dostarczania dóbr użyteczności publicznej, zaś ostatnia stanowi swego rodzaju „gloryfikację" samorządu terytorialnego.

Osiagnięcie przyjętego celu opracowania było możliwe w wyniku analizy literatury przedmiotu.

\section{Model Tiebouta jako „wstęp” do teorii federalizmu fiskalnego}

Szukając w literaturze argumentów za powołaniem samorządu terytorialnego i przyznaniem mu samodzielności jako podstawowego atrybutu jego działania, trudno jest nie odnieść się w pierwszej kolejności do teorii federalizmu fiskalnego i modelu Tiebouta, który rozwijał idee głoszone przez F. Hayeka.

Hayek twierdził, że samorząd terytorialny jest najlepszym dostawcą dóbr i usług, które nie są dostarczane przez rynek w ogóle lub ich dostawa jest zbyt mała w stosunku do zgłaszanego popytu. Jako liberał gospodarczy, sprzyjał konkurencji w zakresie świadczenia usług publicznych, a jednym ze sposobów zapewnienia konkurencji, jego zdaniem, było przekazanie świadczenia usług publicznych powołanemu do tego samorządowi terytorialnemu [Tiebout, 1956, s. 416-424].

1 Tę teorię uważa się za szczególna postać teorii racjonalnego wyboru J. Colemana [Wilkin, 2005, s. 13]. 
Rozwinięciem idei głoszonej przez Hayeka jest model Tiebouta ${ }^{2}$, w którym można odnaleźć argumentację za powierzeniem funkcji alokacyjnej państwa samorządowi terytorialnemu [Tiebout, 1956, s. s. 327-336] ${ }^{3}$. Tiebout twierdził, że różne JST (miasta) moga zaoferować różne zestawy dóbr publicznych przy różnych poziomach opodatkowania mieszkańców (różne koszyki podatkowo-wydatkowe pakiety fiskalne). Obywatele, którzy moga swobodnie się przemieszczać wybiorą sobie do zamieszkania jednostkę terytorialna, w której oferowany jest najlepszy dla nich zestaw usług, nawet za cenę płacenia wyższych danin publicznych. Konkurencja między jednostkami zapewnia, że mieszkańcy dostaja to, czego chca.. Występuje bowiem istotna różnica między centralnym i lokalnym dostarczaniem dóbr publicznych. Na szczeblu centralnym preferencje konsumenta-wyborcy są określone, a rząd stara się dostosować do struktury tych preferencji, podczas gdy na szczeblu lokalnym różna władza może oferować różne zestawy usług przy określonym poziomie swoich dochodów i wydatków. Oferowane zestawy usług będą przyciagać mieszkańców-wyborców do tej wspólnoty, której samorząd najlepiej spełnia ich oczekiwania i proponuje odpowiedni zakres i jakość usług publicznych [Tiebout, 1956, s. 418]. Jest to podstawowy argument ekonomiczny na rzecz lokalnego świadczenia usług publicznych, jednocześnie przemawiający za powołaniem JST. Można bowiem traktować mieszkańców jako konsumentów, przynajmniej w teorii. Mieszkańcy lokalnej wspólnoty, podobnie jak konsumenci moga „dokonywać zakupów" wybierając najlepszą ofertę świadczonych usług publicznych, które chcą konsumować. Tiebout dostrzegał przy tym, że samorządy lokalne mają monopol na świadczenie znacznej części usług, ale zauważał też, że mieszkańcy mogą dokonywać swego rodzaju wyboru zmieniając miejsce zamieszkania pomiędzy JST.

Innym argumentem ekonomicznym przemawiającym za powoływaniem samorządu terytorialnego, który podkreślał Tiebout jest to, że konkurencja sprawia, że władza samorządowa stara się dostarczać dobra i usługi publiczne po konkurencyjnych cenach dla swoich mieszkańców. Rząd centralny nie ma takiej motywacji,

2 Model Tiebouta znalazł zastosowanie w wielu opracowaniach naukowych z zakresu ekonomii sektora publicznego, w tym w pracach takich autorów, jak: George R. Zodrow, Peter Mieszkowski, William A. Fischel i Wallace E. Oates oraz Sock H. Lee. Należy podkreślić, że o ile model Tiebouta w ujęciu pierwotnym dotyczył jednostek mobilnych rozumianych raczej jako osoby fizyczne, będące mieszkańcami konkurujących między sobą wspólnot terytorialnych i konsumentami lokalnych dóbr publicznych, o tyle zwiazane z nim kolejne koncepcje teoretyczne (np. zawarte w opracowaniach G. R. Zodrowa i P. Mieszkowskiego) poruszały już problem mobilnego kapitału inwestycyjnego i dostosowania lokalnych dóbr publicznych do oczekiwań firm.

3 Tiebout w swoim modelu przyjął następujące założenia: mieszkańcy są całkowicie mobilni i dążą do jak najlepszej realizacji swego koszyka dóbr i usług publicznych; mają przy tym pełną wiedzę na temat zestawów dóbr i usług publicznych oraz wysokości danin publicznych we wszystkich JST; mają możliwość szerokiego wyboru zróżnicowanych pakietów fiskalnych oferowanych przez różne JST; w swoich wyborach miejsca zamieszkania nie kierują się możliwościami zatrudnienia; nie ma zależności ekonomicznych pomiędzy JST; każda JST posiada optymalną liczbę mieszkańców, pozwalająca na ponoszenie najniższych kosztów dostarczania dóbr i świadczenia usług publicznych; każda JST, która nie osiagnęła swego poziomu optymalnej liczby mieszkańców będzie dążý do jego uzyskania [Guziajewska 2008, s. 74-75]. 
ani możliwości. Aby uciec od monopolu rządu centralnego, jako dostawcy dóbr i usług publicznych, mieszkańcy musieliby zmienić kraj. Niewiele osób zdecyduje się na opuszczenie swego kraju ze względu na zakres i jakość usług publicznych przy danym poziomie danin publicznych. Może sprzyjać kreowaniu poczucia lokalności, wytworzenia więzi społeczności lokalnej, a to z kolei może przyczyniać się do zachowania wolnego i demokratycznego społeczeństwa oraz świadczenia usług publicznych opartych na „zdrowych zasadach ekonomicznych” [Poniatowicz, Wyszkowska, 2014, s. 73-94]. Można przyjąć, że zaprezentowane przez Tiebouta argumenty przemawiaja za decentralizacja i utworzeniem silnego, „racjonalnie” samodzielnego (autonomicznego) samorządu terytorialnego, opartego na zasadzie subsydiarności mimo wielu zastrzeżeń, co do przyjętych założeń modelu.

Zaproponowany przez Tiebouta model spotkał się z dość dużą krytyka. Podstawowe zastrzeżenia i ograniczenia koncentrują się wokół zawodności rynku oraz kwestii redystrybucji. Problemy związane z zawodnością rynku wiażą się z występowaniem efektów zewnętrznych, niedoskonałą konkurencją i zjawiskiem konkurencji podatkowej, co jest związane z dyskusyjna kwestia przekazania władztwa podatkowego władzom samorządowym [Herber, 1979, s. 329]. Zróżnicowana baza podatkowa JST powoduje poziomą nierównowagę fiskalną, która prowadzi do eksportu podatkowego i konkurencji podatkowej [Gordon, 1983, s. 578; Dalby, 1996, s. 398]. Ponadto należy jednak zauważyć, że w rozumowaniu Tiebouta każda jednostka jest skłonna do zmiany miejsc zamieszkania, będzie kierowała się relacją ilości i jakości dostarczanych dóbr i usług publicznych i wielkościa ponoszonych danin publicznych. W praktyce nie każdy będzie skłonny do „głosowania nogami” z tego powodu. Ponadto w praktyce nie obserwuje się skłonności JST do konkurencji, ani podwyższania efektywności ich działania, zwłaszcza w sytuacji różnego konstruowania systemów zasilania finansowego, często niezachęcającego do działań racjonalizacyjnych.

Z ekonomicznego punktu widzenia wymienione wyżej zjawiska maja zarówno zalety, jak i wady [Broadway, Wildasin, 1992, s. 145]. Oprócz opisanych już zalet, konkurencja podatkowa pomiędzy JST ma także swoje negatywne konsekwencje. Wallace E. Oates ${ }^{4}$ wskazywał, że może ona prowadzić do wyniszczania JST, głównie za względu na ograniczanie dochodów budżetowych, w konsekwencji prowadząc do niedostatecznej podaży lokalnych dóbr i usług publicznych. Może być ona także przyczyna pogłębiającego się zróżnicowania poziomu rozwoju społeczno-gospodarczego JST [szerzej: Stiglitz, 2004, s. 891]. Można by zaryzykować stwierdzenie, że w ostateczności mogłaby prowadzić do oddolnych działań prowadzących do prób odłączenia się jednostek bogatych, dysponujących zdecydowanie większymi dochodami ${ }^{5}$.

4 Przedstawiciel ekonomii sektora publicznego, współautor Local Government Tax and Land Use Policies in the United States: Understanding the Links. Cheltenham, UK: Edward Elgar, $1998 \mathrm{i}$ autor The Economics of Fiscal Federalism and Local Finance, Northampton, MA Edward Elgar, 1998.

5 Tego typu ruchy można obecnie zaobserwować np. w Hiszpanii. 


\section{Samorząd terytorialny w teorii federalizmu fiskalnego I i II generacji}

Omawiana hipoteza Tiebouta dała początek koncepcji federalizmu fiskalnego odnoszacej się do kwestii optymalnej decentralizacji oraz podziału ekonomicznych funkcji państwa $\mathrm{z}$ ustaleniem wieloszczeblowego systemu rządzenia w kontekście zwiększania efektywności i sprawności funkcjonowania sektora publicznego oraz optymalnej alokacji dóbr publicznych [Federalizm fiskalny ..., 2009, s. 16-22] $]^{6}$. Przesłankami tego podziału są głównie efektywność sektora publicznego oraz optymalizacja procesu świadczenia dóbr i usług publicznych, co można osiagnąć jedynie po spełnieniu trzech warunków, a mianowicie: zapewnieniu różnorodności władzy, przyznaniu samodzielności (autonomii) oraz zapewnieniu solidarności finansowej [Poniatowicz, Dziemianowicz 2016, s. 298-299].

Teoria federalizmu fiskalnego zajmuje się z jednej strony podziałem zadań ekonomicznych państwa ${ }^{7}$ pomiędzy różnymi szczeblami zarządzania publicznego (krajowym, stanowym i lokalnym), [Stiglitz, 2004, s. 879], z drugiej zaś instrumentami finansowymi do ich realizacji [Oates, 1999, s. 1121]. Federalizm fiskalny jest procesem prowadzącym do racjonalizacji gospodarowania środkami publicznymi. Wbrew nazwie może mieć miejsce zarówno w krajach federalnych, jak i unitarnych. "Jego istota sprowadza się do specyficznej redystrybucji dochodów publicznych. Część z nich gromadzi się na szczeblu państwa, które ma uprawnienia decyzyjne dotyczące ich przeznaczania łącznie z możliwością zasilania wyodrębnionych struktur administracyjnych zarówno samorządów, jak i stanów, krajów, czy kantonów. Osobną część mogą tworzyć środki gromadzone na innych niż państwo szczeblach, mając uprawnienia do ich ustanawiania, określania formy i rozmiarów, a także przeznaczenia" [Federalizm fiskalny ..., 2009, s. 14-15].

Punktem wyjścia do podziału kompetencji pomiędzy szczeblem centralnym (państwem) a JST w analizowanej teorii są tezy głoszone przez Musgrave’a [Musgrave, 1959]. Według niego finanse publiczne spełniaja trzy funkcje, a mianowicie: alokacyjna, redystrybucyjną i stabilizacyjną. Po analizie korzyści związanych z przeniesieniem tych funkcji na JST zauważył, iż „polityka w zakresie alokacji powinna być możliwa do realizacji przez władze lokalne, w zależności od zgłaszanych preferencji członków społeczności lokalnych [Davoodi, 2001, s. 6]. Natomiast realizacja celów w obrębie funkcji redystrybucyjnej i stabilizacyjnej wymaga przede wszystkim odpowiedzialności na szczeblu centralnym" [Musgrave, 1956, s. 179-182]. Według przedstawicieli analizowanej teorii podstawowa zaletą zdecentralizowanego systemu zadań jest świadczenie dóbr i usług publicznych dostosowanych do potrzeb

6 Za prekursora tej koncepcji uważa się R. A. Musgrave'a, który założenia tej teorii zawarł w opracowaniu: R. A. Musgrave, Theory of Public Finance, McGraw-Hill, New York 1959. Z kolei współczesne rozwinięcie tej teorii w aspekcie finansów lokalnych zawarto w pracy: W. E. Oates, The Economics of Fiscal Federalism and Local Finance, Edward Elgar, Northampton 1998.

7 Jak zauważa H. R. Davoodi podstawową sprawą w federalizmie fiskalnym jest przyporządkowanie określonych kompetencji odpowiedniemu poziomowi rządu. Przyporządkowanie tych kompetencji wpływa na równowage pomiędzy trzema podstawowymi celami polityki fiskalnej: efektywności w alokacji zasobów, redystrybucji dochodów i stabilizowaniu gospodarki. 
mieszkańców poszczególnych JST [Olson, 1969, s. 479]. W federalizmie fiskalnym rozpatruje się nierównowagę $\mathrm{w}$ dystrybucji zasobów i potrzeb pomiędzy rządem federalnym (krajowym) a rządami stanowymi i lokalnymi.

Zakładając, że w państwie istnieją znaczne różnice $\mathrm{w}$ zakresie preferencji dla dóbr i usług publicznych, ich dopasowanie do indywidualnych preferencji (preferencji pewnych zbiorowości) będzie bardziej skuteczne, jeśli ich zaspokajanie będzie odbywało się w sposób zdecentralizowany - przez JST. Argumentem za decentralizacją władzy są także różnice w uwarunkowaniach poszczególnych JST. Sytuacja jednostek samorządu jest zróżnicowana zarówno pod względem warunków geograficzno-przyrodniczych, struktury sektorowej gospodarki, czy też wyposażenia w infrastrukturę. Sprawia to, że władza powinna przywiązywać wagę do celów polityki ekonomicznej, czego nie byłaby w stanie uczynić władza centralna. Także różnice kulturowe moga mieć wpływ na odmienne poglądy dotyczące zakresu oczekiwanej od władzy publicznej interwencji w gospodarkę.

Wynikiem decentralizacji jest zróżnicowane świadczenie dóbr i usług publicznych przy różnych poziomach obciążeń podatkowych. Zdecentralizowany sektor publiczny może również zwiększyć wydajność produkcji i dostarczania dóbr i usług publicznych poprzez wspieranie innowacyjności i poprzez dużą liczbę i różnorodność zdecentralizowanych instytucji. Jest to możliwe dzięki stworzeniu podstaw do dokonywania wyboru najbardziej efektywnych procedur produkcji/świadczenia ze względu na presję konkurencji innych JST. Także zdecentralizowane ramy instytucjonalne systemu zarządzania publicznego moga poprawić publiczne podejmowanie decyzji w taki sposób, że istnieje ścisły związek między zakresem i jakością dostarczanych dóbr i usług publicznych oraz kosztami ich dostawy [Edling, 1998]. JST mogą dostarczyć dobra lub usługi po niższych kosztach uwzględniając bliskość informacji zwrotnych, konkurencję polityczną między jednostkami, czy niższe koszty administracyjne. Zwolennicy federalizmu fiskalnego podkreślają również, że w wyniku przybliżenia władzy do obywateli i zdecentralizowaniu źródeł finansowania nastąi istotny wzrost świadomości podatkowej wśród mieszkańców wspólnot samorządowych i wzrost zainteresowania sprawami lokalnymi oraz zwiększony udział w życiu wspólnoty i w decydowaniu o kierunkach wydatkowania środków budżetowych. W tej sytuacji można oczekiwać także wzrostu akceptacji mieszkańców dla instytucji podatku. Stąd też można uznać, że wprowadzenie federalizmu fiskalnego może odgrywać istotną funkcję edukacyjną we wspólnotach samorządowych.

Jak zaznaczają R. A. Musgrave i P. B. Musgrave, na problemy zdecentralizowanego systemu fiskalnego (federalizmu fiskalnego) zwrócono szczególną uwagę wraz z rozwojem teorii dóbr publicznych. Przedstawiciele federalizmu fiskalnego przypisują szczególną rolę podatkom w finansowaniu JST i decentralizacji fiskalnej. Zastanawiaja się nad cechami poszczególnych dochodów podatkowych, które byłyby najbardziej efektywne na danym szczeblu rządzenia [Musgrave, Musgrave, 1973, s. 519]. Zaznaczaja, że szczebel centralny powinien być finansowany z progresywnego podatku dochodowego od podmiotów gospodarczych oraz podatku od spadków i zasobów naturalnych, szczebel pośredni z podatku dochodowego od osób 
fizycznych, od aktywów posiadanych za granica, ale wywodzących się z terenu JST, podatku od sprzedaży detalicznej oraz podatku od produktu według miejsca pochodzenia, natomiast szczebel lokalny z podatku od nieruchomości, podatku od funduszu płac, jak też opłat i parapodatków za świadczenia na rzecz mieszkańców. Preferowany przez zwolenników federalizmu fiskalnego podział źródeł dochodów podatkowych w państwie zaprezentowano w tabeli 1.

TABELA 1.

\section{Podział źródeł dochodów podatkowych w państwie - podejście standardowe dotyczące poziomu decyzyjnego}

\begin{tabular}{|l|l|l|l|}
\hline \multicolumn{1}{|c|}{ Rodzaje podatków } & $\begin{array}{c}\text { Poziom } \\
\text { centralny }\end{array}$ & $\begin{array}{c}\text { Poziom } \\
\text { regionalny }\end{array}$ & $\begin{array}{l}\text { Poziom } \\
\text { lokalny }\end{array}$ \\
\hline Podatek dochodowy od osób fizycznych & tak & $\begin{array}{l}\text { dodatki do } \\
\text { podatków }\end{array}$ & nie \\
\hline Podatek dochodowy od osób prawnych & tak & nie & nie \\
\hline Podatek od wydobycia surowców naturalnych & tak & ograniczony & nie \\
\hline Podatek od wartości dodanej & tak & nie & nie \\
\hline Podatek od sprzedaży detalicznej & tak & tak & nie \\
\hline Opłaty celne & tak & nie & nie \\
\hline Akcyza & tak & $\begin{array}{l}\text { dodatki do } \\
\text { podatków }\end{array}$ & nie \\
\hline Podatki i opłaty lokalne & nie & nie & tak \\
\hline
\end{tabular}

Źródło: opracowanie własne na podstawie: [Bird, 2011, s. 142].

Podział dochodów ze źródeł podatkowych odgrywa istotną rolę z punktu widzenia wertykalnej równowagi fiskalnej oraz wpływa na horyzontalną (nie)równowagę fiskalną̧ . Podział źródeł podatkowych pomiędzy szczeble zarządzania publicznego i dotyczący ich zakres swobody decyzyjnej jednostek rodzi wiele problemów [por. Darby, Muscatelli, Roy, 2002, s. 18], do których można zaliczyć:

- mobilność czynników produkcji między jednostkami,

- potrzebę równowagi pomiędzy samodzielnością dochodową a stopniem dystrybucji pomiędzy bogatymi a biednymi jednostkami tego samego szczebla zarządzania,

- potrzebę unikania skomplikowania systemu podziału dochodów.

Przekazanie władztwa podatkowego na niższe szczeble zarządzania [por. Ebel, Yilmaz, 2001, s. 36] powinno odbywać się na podstawie ogólnych zasad podziału dochodów, do których należą:

8 Równowaga fiskalna wertykalna (pionowa) odnosi się do wyposażenia szczebla centralnego oraz poszczególnych szczebli JST w dochody adekwatnie do przypisanych im zadań, natomiast równowaga fiskalna horyzontalna (pozioma) do wyposażenia w podobny poziom dochodów JST (potencjał dochodowy) tego samego szczebla (np. gmin). 
- władztwo podatkowe przyznane jednostkom podziału terytorialnego w odniesieniu do czynników mobilnych - powinno dawać swobodę zmiany stawek opodatkowania, bez decydowania o podstawie podatkowej,

- decyzje odnoszace się do opodatkowania wartości dodanej powinny pozostawać w gestii władzy centralnej. Przeniesienie władztwa podatkowego w tym zakresie na niższy poziom zarządzania mogłyby prowadzić do nieefektywnego rozmieszczenia podmiotów gospodarczych,

- dostawa dóbr publicznych na poziomie JST powinna być dokonywana po niższych kosztach niż w przypadku gdyby robił to szczebel centralny i finansowana $z$ dochodów $z$ podatków i opłat, pozostających w bezpośrednim związku z korzyściami otrzymanymi przez konsumentów tych dóbr.

Efektywny podział publicznych dochodów podatkowych powinien umożliwiać poszczególnym JST oraz władzy centralnej pokrywanie wydatków przez osoby faktycznie korzystające $z$ dostarczanych przez nie dóbr publicznych. Dochody podatkowe przypisane JST powinny być pewne i jasno przypisane, aby sprzyjały odpowiedzialności władzy samorządowej za politykę budżetową wspólnoty terytorialnej, a pozyskiwanie dochodów powinno mieć charakter stabilny i przewidywalny.

Przedstawiciele federalizmu fiskalnego są zwolennikami przekazywania kompetencji w zakresie polityki fiskalnej ze szczebla centralnego na rzecz JST. Według nich pewność podstawowego finansowania, decydującego o stopniu samodzielności dochodowej JST, można osiagnąć głównie przez przyznanie im wyłącznego władztwa podatkowego wobec przyznanych im źródeł dochodów (decydowania o podstawie, stawkach i zwolnieniach podatkowych oraz poborze). Zakładaja oni także, że władza samorządowa posiada wiedzę i lepsze rozeznanie lokalnych problemów i potrzeb niż władza centralna, podobnie jak głosił Tiebout. Szerszy zakres lokalnego władztwa podatkowego daje władzy samorządowej większe środki finansowe, które mogą być bardziej efektywnie wykorzystywane dla realizacji bieżących zadań publicznych, jak też kreowania rozwoju lokalnego. W teorii tej nie wyklucza się możliwości stosowania grantów pomiędzy JST (dotyczy subwencji i dotacji ze szczebla centralnego, jak i pomiędzy JST), ale muszą być one dobrze przemyślane. Nie moga być konsekwencja politycznych decyzji w celu przerzucenia kosztów na inne jednostki samorządu [Beeg, 2009, s. 23; Ederveen, Gelauff, Pelkmans, 2008, s. 21-22]. W sytuacji podejmowania konkurencji przez jednostki samorządu dotacje z budżetu państwa powinny być traktowane jako transfery pełniące funkcję stabilizująca i motywująca do konkurowania, a nie transfery redystrybucyjne [Breton, Fraschini, 2004, s. 16].

$\mathrm{Na}$ gruncie analizowanej teorii niezbędne jest także stosowanie systemów wyrównawczych, których celem jest umożliwienie JST świadczenia usług publicznych na zbliżonym poziomie, jeżeli ,poziom ich własnego wysiłku podatkowego (...) jest zbliżony. Oznacza to, że transfery powinny być skierowane do tych jednostek, które mają słabszy potencjał dochodowy i/lub do tych w których koszty wykonywania usług publicznych są na skutek czynników obiektywnych wyższe niż gdzie indziej" [Swianiewicz, 2016, s. 28-29]. 
W poczattkowej fazie rozwoju teorii federalizmu fiskalnego (tzw. federalizmu fiskalnego I generacji - First Generation Theory) nie poruszano zagadnienia upolitycznienia procesu podejmowania decyzji. Przyjmowano, że władza niezależnie od szczebla dąży do maksymalizacji dobrobytu swoich mieszkańców (obywateli). Nie jest natomiast nakierowana na realizację własnych interesów. Kreowaniu polityki nie towarzyszą koszty transakcyjne. Rząd centralny realizuje taką samą politykę na terenie wszystkich JST ${ }^{9}$. W późniejszym czasie poglądy te uległy zdecydowanej zmianie. Przedstawiciele teorii federalizmu fiskalnego II generacji (Second Generation Theory), [Oates, 2005, s. 349-373] zdecydowanie bardziej realistycznie podchodzili do kwestii upolitycznienia procesu podejmowania decyzji oraz realizacji przez władzę własnych interesów, czy występowania kosztów transakcyjnych, wykorzystując w tym zakresie dorobek teorii wyboru publicznego ${ }^{10}$ [Wilkin, 2012, s. 9-30]. Przedstawiciele opisywanej teorii II generacji koncentrują się na procesach i czynnikach politycznych, przyjmując za punkt wyjścia założenie, że w zasadzie wszyscy uczestnicy procesów decyzyjnych kieruja się w swoich działaniach i decyzjach indywidualnymi preferencjami i korzyściami, forsując swoje partykularne interesy, nie zwracając uwagi na dobro publiczne. Przekłada się to na wyniki systemowe, również te dotyczące systemu finansów publicznych, w tym systemu finansów samorządowych [Poniatowicz, Dziemianowicz, 2016, s. 300]. Stąd w doktrynie tej akcentuje się problem zawodności władzy publicznej.

Oates rozwinął ekonomiczne podejście do federalizmu, stwierdzając, że są dwa przeciwstawne typy rządu. Występuje albo całkowita centralizacja: jednolita forma rządu, ponoszącego pełną odpowiedzialność za realizację wszystkich trzech funkcji gospodarczych sektora publicznego, albo pełna decentralizacja. Zauważa jednak, że w praktyce nie występuje pełna decentralizacja, która może prowadzić do anarchii. Raczej, może wystąpić wysoki poziom decentralizacji, w której rząd centralny jest niemal pozbawiony odpowiedzialności ekonomicznej. Oates rozważał przy tym zalety i wady obu wymienionych rozwiązań. Centralizacja jest zdecydowanie korzystniejsza z punktu widzenia funkcji stabilizacji i redystrybucji, ale zdecentralizowana jest lepsza dla realizacji funkcji alokacyjnej ze względu na niejednolitość potrzeb społeczności lokalnych. Świadczenie zróżnicowanych terytorialnie usług przez lokalne władze będzie zawsze bardziej wydajne, efektywne, a przynajmniej skuteczniejsze niż przez rząd centralny [Oates, 1972, s. 35]. Oates podkreślał, że należy poszukiwać rozwiązań takich form rządów, które łączyłyby w sobie zalety i pozwalały unikać wad każdego z rozwiązań. Federalizm fiskalny w jego rozumieniu stanowił, w pewnym sensie, kompromis między wymienionymi typami rządów i pozwalał na realizację wszystkich funkcji w sposób najlepszy, najbardziej efektywny [Musgrave, 1956]. Według Oatsa „poziom dobrobytu będzie zawsze wyższy jeśli

9 Założenie to wynikało przede wszystkim z tego, że pozyskanie informacji odnośnie preferencji lokalnych społeczności powodowałoby konieczność ponoszenia kosztów, które byłyby wyższe niż w sytuacji pozyskiwania tych informacji przez władzę lokalną.

10 Wallace E. Oates określa ten aspekt mianem public-choice perspectives on fiscal federalism [Oates, 2005, s. 355]. 
poziom konsumpcji lokalnego dobra publicznego będzie ustalany przez każda jednostkę terytorialna $\mathrm{z}$ osobna $\mathrm{w}$ porównaniu $\mathrm{z}$ narzucaniem tej wielkości $\mathrm{z}$ góry w przypadku występowania efektów zewnętrznych i braku ograniczeń kosztów" [Oates, 1972, s. 54].

Zaprezentowane poglądy przedstawicieli federalizmu fiskalnego jednoznacznie wskazuja na zasadność powołania samorządu terytorialnego i przyznania mu znacznego zakresu samodzielności finansowej zapewniającej sprawność działania jednostek. Jest to uzasadnione przede wszystkim lepszym zaspokojeniem potrzeb zbiorowych mieszkańców oraz wzrostem efektywności gospodarowania ograniczonymi środkami publicznymi. W zaprezentowanej koncepcji można dopatrzeć się wielu mankamentów, odnoszących się do przyjętych założeń, zwłaszcza w początkowej jego fazie (I generacji federalizmu) - braku upolitycznienia władzy lokalnej. Ponadto problematyczna i poddawana obecnie szerokiej krytyce jest konkurencja pomiędzy JST, szczególnie w zakresie podatkowym. Może ona bowiem prowadzić do wyniszczania jednostek. Także przyznanie wysokiego stopnia samodzielności, we wszystkich aspektach, ale przede wszystkim finansowym, może powodować do marginalizację części jednostek i problemy z realizacja przypisanych im zadań publicznych. Wykorzystanie jej założeń w praktyce wymagałoby od władzy lokalnej przyjęcia pełnej odpowiedzialności za działania nakierowane na interes publiczny.

\section{Samorząd terytorialny $w$ teorii wyboru publicznego}

Kolejną teorią, którą można posłużyć się do wyjaśnienia znaczenia i zasadności powoływania samorządu terytorialnego, jest powstała w drugiej połowie XX wieku - teoria wyboru publicznego ${ }^{11}$. Jej twórcy i zwolennicy występuja przeciwko nadmiernej ingerencji państwa $\mathrm{w}$ gospodarkę, przyczyniającej się do działania zorganizowanych grup nacisku. W centrum uwagi teorii wyboru publicznego leży problem niesprawności państwa. W tym celu przedstawiciele tej teorii badają zachowania rządu, parlamentu, efektywność władzy oraz biurokracji państwowej. Zajmują się funkcjonowaniem systemów politycznych, instytucji politycznych wykorzystując analizę ekonomiczna. Przyjmują oni, że o sprawności sfery politycznej decyduje jakość instytucji, w których podejmowane są wybory i decyzje dotyczące całych zbiorowości, a dokonywane przez pojedyncze osoby, które w swoich decyzjach kierują się zasadą ekonomizacji. Siłą napędową decyzji i działań,

11 W ramach tej teorii rozwinęło się wiele nurtów. Na szczególną uwagę zasługują: ekonomiczna teoria demokracji (A. Downs), ekonomia konstytucyjna (J. Buchanan, G. Tullock), teoria biurokracji (W. Niskanen), teoria grup interesu (M. Olson), czy teoria pogoni za rentą (G. Tullock). Teoria wyboru publicznego rozwinęła się głównie w trzech ośrodkach: Virginii, Chicago i Rochester. Jednak najbardziej wpływowym, zajmującym się wyborem publicznym jest szkoła z Virginii. Prekursorem tej teorii jest D. Black, który zajmował się badaniem rynków politycznych w celu określenia warunków osiagnięcia równowagi w polityce [Black, 1948, s. 23-34]. Przełomowe znaczenie dla rozwoju analizowanej teorii miały prace A. Downsa, J. M. Buchanana i G. Tullocka [szerzej: Przesławska, 2003]. 
niezależnie czy mają one charakter prywatny, czy też publiczny, jest własny, indywidualny interes obywateli i urzędników. Głównym celem tych podmiotów jest zatem maksymalizacja ich indywidualnych korzyści oraz minimalizacja własnych kosztów. Jak stwierdził Buchanan, „sfera polityczna, wybór publiczny jest polityką bez sentymentów, a więc polityką opartą na chłodnej kalkulacji ekonomicznej" [Wilkin, 2005, s. 13]. W swoich decyzjach i działaniach mieszkańcy, urzędnicy, czy włodarze kierują się funkcją użyteczności jednostki. Mieszkaniec-konsument, kierując się własnym interesem i dążąc do maksymalizacji użyteczności, jest zainteresowany tylko takim zestawem dóbr i usług publicznych, które pozwalają mu te cele osiagnaćc. Natomiast konkurujący między sobą producenci dóbr i usług publicznych (w tym przypadku władza samorządowa), kierując się własnymi celami (politycy - reelekcją, urzędnicy - możliwością awansu), starają się zaspokajać popyt zgłaszany przez obywateli-konsumentów.

Przedstawiciele tej teorii głosili jednak, że optymalnym mechanizmem kształtującym popyt i podaż na dobra, w tym publiczne jest rynek. Nawet wobec zastapienia tego mechanizmu przez interwencję państwa, dokonując alokacji dóbr publicznych powinno kierować się odpowiednimi sprecyzowanymi kryteriami wyboru, podobnymi do tych dotyczacych alokacji dóbr prywatnych [szerzej: Owsiak, 2006, s. 83-95].

Elementem różniącym rynek dóbr prywatnych i publicznych jest sposób podejmowania decyzji dotyczących alokacji poszczególnych zasobów. Decyzje dotyczące dóbr publicznych mają charakter „zbiorowy”. Anthony Downs zauważył, że „koncepcje rządu, których nie można znaleźć bezpośrednio w tradycyjnej teorii ekonomii, nie są spójne z aksjomatami, którymi wyjaśnia się działanie sektora prywatnego" [Michalak, 2005, s. 70]. W sektorze publicznym to od wybranych przez społeczeństwo przedstawicieli, wyborcy oczekują reprezentowania własnych interesów. Problemem jest jednak właściwe ustalenie preferencji wyborców, które nawet wśród jednorodnego elektoratu moga być zupełnie różne. Z publicznym mechanizmem alokacji zasobów wiąże się także tzw. problem ujawniania preferencji. Według J. E. Stiglitza wybór określonych polityków dostarcza jedynie ograniczonej informacji o preferencjach wyborców do konkretnych dóbr publicznych ${ }^{12}$. Uwzględniając zaprezentowane słabości demokracji przedstawicielskiej pojawia się tendencja do

12 Knut Wicksell prowadził analizy dotyczące skutecznego dostarczania dóbr publicznych w sytuacji braku możliwości ujawniania indywidualnych preferencji. W jego koncepcji system podatkowy powinien być oparty na indywidualnych preferencjach: dostarczanie dóbr i usług publicznych oraz ich finansowanie powinno być zorganizowane na zasadach podobnych do transakcji rynkowych. Ustalona przez Wicksella zależność oznacza związek pomiędzy ilością konkretnego dobra lub usług dostarczanych przez sektor publiczny a wysokością opłat i podatków, które mieszkańcy musza płacić za te dobra i usługi. Zgodnie z tym modelem można stwierdzić, iż jeżeli decyzje dotyczące wydatków publicznych i ich finansowania są podejmowane jednocześnie i na zasadach jednomyślności pomiędzy tymi dwiema zmiennymi pojawia się ścisły związek. W literaturze pojawił się argument, że konkurencja pomiędzy władzami lokalnymi, jeśli jest konkurencją doskonałą i niezniekształcaną przez brak informacji, również powinna generować całkowicie ścisłe zależności wickselliańskie. Model efektywności w dostępie do dóbr publicznych jest jedynie konstrukcją teoretyczną i jako taki ma niewielkie znaczenie praktyczne [Guziajewska, 2008, s. 77-80]. 
nadprodukcji dóbr. Obok niej charakterystyczne staje się narastanie deficytu budżetowego będącego skutkiem braku efektywności dostawy dóbr i usług publicznych.

Mimo zawodności rynku ma on zawsze przewagę nad sektorem publicznym. Decyduje o tym konkurencja, której pozytywnymi rezultatami są obfitość, dostępność i różnorodności dóbr i usług rynkowych. Jak zauważali przedstawiciele analizowanej teorii, klasycznym przykładem braku konkurencji w postaci monopolu jest samorząd terytorialny dostarczający usługi publiczne przez własne zakłady administracyjne działające na określonych terytorialnie obszarach. Samorząd funkcjonuje poza rynkiem konkurencyjnym, nie może zbankrutować, a mieszkańcy nie mają wyboru, jakim mogą kierować się konsumenci na rynku [Szarfenber, 2016, s. 3]. Stąd przedstawiciele teorii wyboru publicznego podkreślali nieefektywność działania JST i postulowali konieczność reform zmierzających do ${ }^{13}$ :

- zawierania kontraktów z firmami prywatnymi i dopuszczenie konkurencji (conracting-out),

- rozczłonkowania struktur samorządowych (fragmentaryzacja biurokracji),

- zwiększenia roli ekspertów i uzależnienia ich wynagrodzenia od efektywności działania (uzyskiwanych oszczędności).

Zastanawiali się nad tym, jak wprowadzić konkurencję pomiędzy jednostkami samorządu i dać wybór do zróżnicowanych lokalnych usług publicznych. Jednym z takich rozwiązań jest prywatyzacja, ale nie jest jedyną. Zwolennicy analizowanej teorii sa za urynkowieniem sektora usług publicznych, w tym lokalnych. Pozwalał on na dokonywanie wyboru mieszkańcom i wymuszeniu konkurencji między mniejszymi jednostkami samorządu lub między jednostkami publicznymi świadczącymi określoną usługę [Ostrom, Tiebut, Warrner, 1961]. Zwolennicy tej teorii prezentują poglądy, podobnie jak przedstawiciele federalizmu fiskalnego, przemawiające za decentralizacja fiskalna, przyznając jednostkom samorządu terytorialnego szeroki zakres władztwa podatkowego wobec zdecentralizowanych źródeł ich dochodów ${ }^{14}$. Wskazują także na korzyści wynikające z konkurencji podatkowej między JST, które skutkują niższymi podatkami i ograniczaja wzrost jednostek lokalnych [Brennan, Buchanan, 1980]. Przypisanie JST podatkowych źródeł dochodów i przyznanie im wobec nich instrumentów władztwa podatkowego sprawia, że władza samorządu lokalnego staje się $\mathrm{w}$ pełni odpowiedzialna za swoje wydatki nakierowane na zaspokajanie lokalnych potrzeb wspólnoty. Ma istotny wpływ na cenę, jaką należy zapłacić za usługi publiczne, z których korzysta społeczność lokalna. Biorąc pod uwagę fakt, że obywatele są świadomi kosztów oferowanych usług publicznych, władze JST będa miały silną motywację, aby racjonalnie zarządzać swoimi budżetami [De Mello, 1999, s. 3-25].

Można zatem stwierdzić, że przedstawiciele analizowanej teorii byli także zwolennikami samorządu terytorialnego, jednak pobudki, jakimi się oni kierowali były

13 lex.online.wolterskluwer.pl/WKPLOnline/index.rpc [data wejścia: 12.12.2016].

14 Na szczególną uwage zasługuja: ekonomiczna teoria demokracji (A. Downs), ekonomia konstytucyjna (J. Buchanan, G. Tullock), teoria biurokracji (W. Niskanen), grup interesu (M. Olson), czy pogoni za rentą (G. Tullock). 
zdecydowanie odmienne niż w przypadku przedstawicieli federalizmu fiskalnego. Można zaryzykować stwierdzenie, że w przypadku pierwszych uznawali oni dostawę dóbr publicznych przez JST za „mniejsze zło” niż miałoby to miejsce w przypadku państwa. Uznawali oni jednak wyższość rynku jako regulatora dostawy dóbr i usług, w tym również publicznych.

Teoria wyboru publicznego została poddana krytyce przez zwolenników samorządu terytorialnego, którzy podkreślali, że:

- samorządu nie można rozliczać według reguł obowiązujących w gospodarce rynkowej,

- $\quad$ zasady gry rynkowej nie są do pogodzenia z mechanizmem reprezentatywności, ponieważ wykluczenie ekonomiczne może uniemożliwiać udział w sferze publicznej.

\section{Samorząd terytorialny $\mathrm{w}$ teorii lokalizmu}

Kolejną z teorii samorządu terytorialnego, stanowiąca gloryfikację tego samorządu jest teoria lokalizmu (rozwinięta w latach 70. i 80. XX wieku). Przyczyn jej rozwoju należy upatrywać w ociężałości struktur państwowych, ich niewydolności, niskiej efektywności, a także ponoszeniu zbyt dużych kosztów realizacji funkcji publicznych. Argumentów za tworzeniem samorządu terytorialnego dostarczali J. Stewart i G. Jones, którzy są uważani za prekursorów analizowanej teorii [Domagała, Iwanek, 2013, s. 18]. Jest ona koncepcją przeciwstawną do teorii wyboru publicznego. Uznawana jest często za oficjalną ideologię samorządu terytorialnego. Konieczność powoływania samorządu terytorialnego wynika, według jej twórców, z potrzeby stworzenia przeciwwagi dla rządu centralnego. Istnienie samorządu terytorialnego pozwala na przeniesienie władzy na niższe szczeble (rozpowszechnienie demokratycznej władzy w społeczeństwie), dzięki czemu staje się ona bardziej dostępna i elastyczna, co sprzyja podejmowaniu efektywniejszych decyzji w społecznościach lokalnych. Jest to możliwe dzięki temu, że władza samorządowa, zna i może wziąć pod uwagę zróżnicowane, lokalne potrzeby, preferencje i problemy, w przeciwieństwie do władzy centralnej [Samorzad terytorialny, 2013, s. 46-47]. Pozwala to na funkcjonowanie mechanizmu dopasowywania dostępnych środków finansowych JST do potrzeb mieszkańców wspólnot samorządowych.

Twórcy tej teorii popierali powołanie stosunkowo niewielkich wspólnot samorządowych, podobnie jak przedstawiciele teorii wyboru publicznego ${ }^{15}$. Twierdzili,

15 Optymalna wielkość JST jest często podejmowanym tematem dyskusji naukowej i politycznej. Rozważania na ten temat można odnaleźć m.in. w pracach K. Dowdinga [Dowding, John, Biggs 1994, s. 767-797], czy też G. A. Boyne’a [Boyne, 2003, s. 367-394]. Podsumowanie teoretyczne argumentów przyjmowania różnych rozwiązań w tym zakresie można znaleźć w opracowaniu M. Keating, Size, efficiency and democracy: consolidation, fragmentation and public choice. Przegląd najistotniejszych argumentów za funkcjonowaniem zarówno małych, jak i dużych JST szczebla podstawowego można odnaleźć w artykule Swianiewicza, który dokonuje przeglądu literatury światowej na ten temat [Swianiewicz, 2009]. 
że dzięki organizacji niedużych jednostek istnieje większa „widzialność” i odpowiedzialność władzy samorządowej za podejmowane decyzje. W ramach tego typu organizacji może lepiej funkcjonować kontrola społeczna i być budowane zaufanie społeczne. Powinno to także pozwalać na aktywizowanie lokalnej społeczności, generowanie innowacji oraz promowanie pluralizmu. „Samorząd będąc mniej odległy sprawia, że władza może postępować bardziej spójnie, umożliwia to jasny i zrównoważony wybór dotyczący promowania wartości wyznawanych przez społeczność lokalną" [Domagała, Iwanek, 2013, s. 19]. Wśród argumentów za tworzeniem małych jednostek wskazywali zatem argumenty wymienione wcześniej na rzecz alokacji dóbr publicznych na najniższym poziomie rządów [Bukowska, 2008, s. 48]. W rozwoju lokalizmu widziano potencjał do wychodzenia z obszaru cywilizacyjnego niedorozwoju państw.

Atrybutami tworzonego lokalizmu miały być „względna autonomia oraz upodmiotowienie w zakresie gospodarczym i społecznym konkretnych społeczności lokalnych w ramach szerszego układu społeczno-przestrzennego i politycznego" [Domagała, Iwanek, 2013, s. 19]. Zwolennicy lokalizmu przypisywali JST znaczny zakres samodzielności, w zasadzie w każdym aspekcie jej funkcjonowania, zwracając uwagę na podstawowe wartości, na których opiera się „lokalizm”, a mianowicie [A. Kaczorowska-Budek, 2014, s. 150]:

1) subsydialność (zasada pomocniczości),

2) samorządność,

3) decentralizacja,

4) demokracja.

Teoria ta doczekała się nowego ujęcia określanego w literaturze mianem koncepcji nowego lokalizmu. Pojawiła się ona w naukach politycznych pod koniec lat 80. i na początku 90. XX wieku wraz z ,nową polityką miejską” (G. Goetz i S. E. Clarke) w USA, a następnie w Wielkiej Brytanii. Zwolennicy nowego lokalizmu stoją na stanowisku, że potrzebny jest silny, otwarty i elastyczny samorząd lokalny, który powinien być „strażnikiem” w sferze publicznej, obrońcą mieszkańców-konsumentów, popierającym realizację celów społecznych i obywatelskich oraz kreatorem rozwoju gospodarczego. Jednocześnie nie twierdzą oni, że samorząd powinien wykonywać wszystkie zadania publiczne, a szczebel centralny powinien zaprzestać realizacji zadań publicznych. Samorząd terytorialny powinien realizować te zadania, które wykonuje lepiej, skuteczniej, w sposób efektywniejszy niż centrum, dysponując bardziej racjonalnie i efektywnie ograniczonym środkami publicznymi.

W centrum jej zainteresowania pozostaje nadal koncepcja rozwoju lokalnego, opartego na społecznościach i wartościach lokalnych, choć w większym stopniu uzależniona od interakcji z jednostkami ponadlokalnymi. W ramach koncepcji nowego lokalizmu podejmowane są m.in. następujące kwestie: stopnień samodzielności, aktywności i podmiotowości JST, udział samorządów lokalnych w finansach państwa, czy też rola państwa w kreowaniu warunków oddolnego rozwoju. Przedstawiciele tej koncepcji postulują doskonalenie regulacji prawnych odnoszących się do funkcjonowania władz samorządowych, zwłaszcza w sferze finansów [szerzej: A. Sztando, 2017, s. 284]. 
Koncepcja ta podobnie, jak i pozostałe prezentowane została poddana krytyce. Wśród kwestionowanych elementów znalazło się ${ }^{16}$ :

- przedkładanie potrzeb społeczności lokalnych nad zasady sprawiedliwości społecznej,

- nieuzasadniona wiara w mechanizmy polityki lokalnej,

- niebezpieczeństwo korupcji i nepotyzmu,

- nieefektywność organizacyjna i tendencje do biurokratyzowania się,

- przecenianie zdolności do reform.

Przedstawiciele lokalizmu widzieli potrzebę reformowania systemu samorządowego jako niedoskonałego. Postulowali oni [Samorzad terytorialny, 2013, s. 47]:

- precyzyjny podział zadań między państwo a JST,

- wprowadzenie lokalnego podatku dochodowego,

- zastosowanie proporcjonalnego systemu wyborczego,

- wprowadzenie jednego szczebla samorządowej organizacji terytorialnej (lokalnego).

Mimo wskazanych niedoskonałości, przedstawiciele analizowanej koncepcji dostrzegali znacznie więcej zalet i korzyści związanych z oparciem rozwoju na zdecentralizowanych jednostkach lokalnych niż pozostawienie odpowiedzialności za bieżące funkcjonowanie i rozwój władzy centralnej.

Teoria lokalizmu stanowi swego rodzaju gloryfikację samorządu terytorialnego. Jej zwolennicy przeciwstawiali lokalizm szerzącym się procesom globalizacji i uważali go za panaceum na wszelkie niedoskonałości. Choć sami dostrzegali niedoskonałości samorządu uważali go jednak za najlepszą formę zarządzania państwem i społeczeństwem, wychodząc od oddolnych inicjatyw społecznych tworzących swego rodzaju więzi i dążących do zaspokajania potrzeb małych wspólnot samorządowych.

\section{Podsumowanie}

We współczesnej teorii ekonomii istnienie wiele koncepcji odnoszących się do znaczenia samorządu terytorialnego i konieczności przypisania mu określonych atrybutów samodzielności. Wśród nich szczególne miejsce zajmuje teoria federalizmu fiskalnego należąca do grupy teorii, których podstawą jest krytyka mechanizmów dostarczania dóbr użyteczności publicznej. Do tej samej grupy można zaliczyć także analizowaną $\mathrm{w}$ artykule teorię wyboru publicznego, jak też teorię nowego zarządzania publicznego, czy też nową ekonomię instytucjonalną.

Teoria federalizmu fiskalnego koncentruje się głównie wokół kwestii zawodności rynków oraz wydajnego i sprawiedliwego dostarczania dóbr publicznych. Natomiast teoria wyboru publicznego odnosi się do zawodności (niesprawności) państwa.

16 http://docplayer.pl/46193638-1-koncepcja-lokalizmu-koncepcja-uznawana-za-oficjalna-ideologiesamorzadu-koniecznosc-istnienia-samorzadow-jako-przeciwwagi-dla-rzadu-kompetencje-r.html [data wejścia: 04.04.2018]. 
Trzecia z analizowanych teorii - lokalizmu stanowi gloryfikację samorządu terytorialnego - jako jego oficjalną ideologia. Jest teoria przeciwstawną do teorii wyboru publicznego. Fundamentalną cechą samorządu terytorialnego jest dyfuzja władzy, która staje się bardziej dostępna i elastyczna, przez co sprzyja podejmowaniu decyzji w różnych społecznościach lokalnych w sposób bardziej efektywny.

U podstaw przedstawionych teorii leżą inne podstawy. W odmienny sposób ich przedstawiciele podchodzą do uzasadnienia powołania samorządu terytorialnego jako odpowiedzi, z jednej strony - na zawodność rynku, z drugiej - zawodność państwa. W różny sposób odnoszą się też do samego funkcjonowania samorządów i jego wad, jak też działań, które moga być podejmowane w celu ograniczania skutków tych wad.

Przedstawione teorie, mimo zasadniczo odmiennych założeń teoretycznych, pozwalają wyciąnąć jednak podobne wnioski. Reprezentanci wszystkich omówionych koncepcji teoretycznych ostatecznie przedstawiaja pogląd, że podejmowanie decyzji, co do alokacji dóbr publicznych, w określonej części, powinna być dokonywane na najniższym poziomie zarządzania, aby była ona jak najbardziej skuteczna i efektywna. W przypadku federalizmu fiskalnego powinny być to jednak jednostki większe niż w pozostałych dwóch analizowanych teoriach, ze względu na możliwość osiagania określonych korzyści z ich funkcjonowania oraz możliwości i skuteczności decentralizacji fiskalnej. Wśród argumentów na rzecz alokacji dóbr na niższym szczeblu zarządzania można wymienić:

- lepszy kontakt władzy lokalnej z mieszkańcami,

- możliwość maksymalizują użyteczności mieszkańców (relacja dostawa dóbr i usług - wysokość płaconych danin publicznych),

- ograniczenie biurokracji,

- bardziej efektywną alokację kapitału (ze względu na współzawodnictwo w walce o inwestycje),

- skłonność do eksperymentów i innowacji w odniesieniu do mniejszych jednostek przestrzennych,

- decentralizację sprzyjającą rozwiązaniom rynkowym i przyczyniającą się do redukcji sektora publicznego,

- możliwość wprowadzenia między jednostkami konkurencji sprzyjającej wzrostowi efektywności ich funkcjonowania.

Ponadto przedstawiciele przedstawionych teorii zauważyli, że korzyści skali nie mają znaczenia w sytuacji, gdy można dokonywać rozdzielenia odpowiedzialności za usługi od ich świadczenia, np. w drodze zawierania kontraktów z firmami prywatnymi. Podkreślali też lepsze zaspokojenie potrzeb wspólnot mieszkańców i skuteczniejsze wykorzystanie zgromadzonych środków budżetowych. Byli również zwolennikami konkurencji pomiędzy tworzonymi jednostkami samorządu terytorialnego.

Nieodzownym elementem funkcjonowania samorządu terytorialnego jest przypisanie JST podstawowego atrybutu, jakim jest samodzielność, rozpatrywana w różnych aspektach. Samodzielność jest eksponowana zwłaszcza w teorii federalizmu fiskalnego, której przedstawiciele rozważają w szerokim zakresie kwestie decentralizacji fiskalnej. Podkreślają, że decentralizacji zadań publicznych powinna towa- 
rzyszyć decentralizacja źródeł ich finansowania. Jednostki samorządu terytorialnego powinny zostać wyposażone w źródła dochodów, którymi mogłyby dysponować w celu realizacji zaspokajania potrzeb wspólnot samorządowych. Proces decentralizacji finansów publicznych powinien sprzyjać dbałości o źródła pozyskiwania dochodów przez JST oraz racjonalnemu, efektywnemu wykorzystaniu środków budżetowych na rzecz dostawy dóbr i świadczenie usług publicznych. Kwestie te również były przedmiotem rozważań w teorii lokalizmu oraz teorii wyboru publicznego, jednak w zdecydowanie węższym zakresie. W ostatniej z wymienionych teorii, podkreślano zwłaszcza zagadnienia związane z konkurencja podatkowa, wywierającą istotny wpływ na efektywność działania władzy samorządowej.

\section{Literatura}

Begg I., 2009, Fiscal Federalism, Subsidiarity and the EU Budget Review, Report No. 1, Swedish Institute for European Policy Studies, Stockholm.

Beer-Tóth K., 2009, Local Financial Autonomy in Theory and Practice. The Impact of Fiscal Decentralization in Hungary, Fribourg.

Bird R. M., 2011, Subnational taxation in developing countries: a review of the literature, "Journal of International Commerce, Economics and Policy", t. 2, nr 1.

Black D., 1948, On the Rationale of Group Decision-Making, "The Journal of Political Economy", t. 56, nr 1.

Boyne G. A., 2003, Sources of Public Service Improvement: A Critical Review and Research Agenda, "Journal of Public Administration Research and Theory", t. 13(3).

Brennan R., Buchanan J., 1980, The Power of Tax: Analytucal Foundations os a Fiscal Constitution, Cambrige University Pess, Cambrige, MA.

Breton A., Fraschini A., 2004, Intergovernmental equalization grants: some fundamental principles, Department of Public Policy and Public choice - POLIS, Working paper no. 42, www.polis.unipmn.it.pubbl [data wejścia: 12.02.2015].

Broadway R., Wildasin D., 1984, Public sector economics, Boston.

Bukowska G., 2008, Teoretyczne podstany podriatu kompetencï pomiedsy władzami centralnymi a lokalnymi, [w:] Samorzad lokalny - dobro publiczne, J. Kleer (red.), CeDeWu.pl, Warszawa.

Dalby B., 1996, Fiscal externalities and the design of intergovernmental grants, "International Tax and Public Finance", nr 3.

Darby J., Muscatelli A. V., Roy G., 2002, Fiscal federalism and fiscal autonomy: lessons for the UK from other industrialized countries, University of Glasgow, September, www. strath.ac.uk [data wejścia: 21.12.2016].

Davoodi H., 2001, Fiscal Decentralization, IMF Research Bulletin, t. 2, nr 2.

De Mello L., 1999, Interovernmental fiscal relations, coordination failures and fiscal outcomes, Public Budgeting and Finance, t. 19.

Domagała M., Iwanek J., 2013, Regionalne i lokalne ustroje polityczne, cz. I, „Studia Politicae Universitatis Silesiensis", t. 10.

Dowding K., John P., Biggs S., 1994, Tiebout: A Survey of the Empirical Literature, "Urban Studies", t. 4-5(31). 
Ebel R. D., Yilmaz S., 2001, Le concept de décentralisation fiscal et survol mondial, Symposium International Commission sur le Déséquilibre Fiscal, Quebec, 13 et 14 septembre, www.desequilibrefiscal.gouv.qc.ca [data wejścia: 21.12.2016].

Ederveen S., Gelauff G., Pelkmans J., 2008, Assessing Subsidiarity, [in:] Subsidiarity and Economic Reform in Europe, Springer.

Edling H., 1998, Non-Tax Revenue of Subnational Governments: Theoretical Background, Experience from The International Perspective and Recommendations, Economic Commission For Latin America and The Caribbean, Fiscal Policy Series, nr 105.

Faliński S., 2014, Zróżnicowanie samorz̨adu terytorialnego w państwach Unii Europejskiej, „Kwartalnik Naukowy Uczelni Vistula”, nr 3(41).

Federalizm fiskalny w teorii i praktyce, 2009, Piotrowska-Maczak K. (red.), Difin, Warszawa.

Filipiak B., Dylewski M., 2016, Źródta dochodów własnych samorzadu województwa w świetle ich samodzielności dochodowej na prayktadrie województwa zachodniopomorskiego, „Annales Universitatis Mariae Curie-Skłodowska Lublin - Polonia”, Sectio H, t. L, 1.

Gordon R., 1983, An optimal taxation approach to fiscal federalism, "Quarterly Journal of Economics", nr 4(93).

Guziajewska B., 2008, Efektywność finansów samorzadu terytorialnego, „Gospodarka Narodowa", nr 5-6.

Hartwich O., A Global Perspective on Localism, The New Zealand Initiative, Wellington, http://www.lgnz.co.nz/assets/Publications/A-global-perspective-on-localism.pdf [data wejścia: 20.12.2014].

Herber B. P., 1979, Modern public finance, Richard D. Irwin INC, Illinois.

Jones G., Stewart J., 1983, The Case for Local Government, Allen \& Unwin, London.

Kaczorowska-Budek A., 2014, U źródet marketingu terytorialnego, „Handel Wewnętrzny", nr 2(349).

Kozuń-Cieślak G., 2009, Federalizm fiskalny $i$ nowe zarzadz̧anie publiczne - podejscie teoretyczne do roli $i$ zakresu kompetencji samorzadón terytorialnych, „Zeszyty Naukowe Uniwersytetu Szczecińskiego", Ekonomiczne Problemy Usług, V Forum Samorządowe. Samorząd Terytorialny w Zintegrowanej Europie nr 29.

Krelove R., 1992, Efficient tax exporting, "Canadian Journal of Economics", nr 1(25).

Oates W. E., 1999, An Essay on Fiscal Federalism, "Journal of Economic Literature", t. XXXVII.

Oates W. E., 1972, Fiscal Federalism, Harcourt Brace Jovanovich, Inc, New York.

Olson M., 1969, The Principle of "Fiscal Equivalence". The Division of Responsibilities among Different Levels of Government, "The American Economic Review", t. 59(2).

Michalak T., 2005, Ekonomiczna teoria demokragi Anthony'ego Downsa, [w:] Teoria myboru publicznego, J. Wilkin (red.), Wydawnictwo Scholar, Warszawa.

Musgrave R. A., 1956, Public finance in theory and practice, McGrow-Hill Book Company, New York.

Musgrave R. A., Musgrave P. B., 1973, Public finance in theory and practice, McGrow-Hill Book Company, Fourth edition, New York.

Onofrei M., 2007, Administrație publică. Fundamente științifice şi bune practici, Iași: Alexandru Ioan Cuza University Publishing. 
Ostrom V., Tiebut C., Warren R., 1961, The Organization of Government in Metropolitan Areas: A Theoretical Inquiry, "The American Political Science Review", t. 55, nr 4.

Owsiak S., 2006, Finanse publiczne. Teoria i praktyka, PWN, Warszawa.

Poniatowicz M., Dziemianowicz R., 2016, Udziaty samorzqdu terytorialnego w państwowych podatkach dochodowych $w$ aspekcie postulatów teoretycznych federalizmu fiskalnego, Annales Universitatis Mariae Curie-Skłodowska Lublin - Polonia, t. L, 1 Sectio H.

Poniatowicz M., Wyszkowska D., 2014, Stymulowanie rozwoju lokalnej przedsiębiorczości a konkurencja podatkowa gmin, [w:] Finansowe i podatkowe aspekty rozwoju przedsiebiorczości w regionach, Dylewski M. (red.), „Zeszyty Naukowe Wyższej Szkoły Bankowej w Poznaniu", t. 52, nr 1.

Pratchett L., 2004, Local autonomy, local democracy and the New Localism', "Political Studies", t. 52.

Przesławska G., 2003, Ekonomiczna rola państwa w ujęciu nowej ekonomii politycznej, [w:] Regulowana gospodarka rynkowa, U. Kalina-Prasznic (red.), Oficyna Ekonomiczna, Kraków.

Samorzad terytorialny. Zasady - Finanse - Marketing, 2013, M. Stych (red.), Oficyna Wydawnicza Edytor.org, Częstochowa.

Stiglitz J. E., 2004, Ekonomia sektora publicznego, PWN, Warszawa.

Swianiewicz P., 2016, Wyrównywanie poziomie sytuacji finansowej jednostek samorzqdu terytorialnego - doświadczenia europejskie, „Studia Regionalne i Lokalne”, nr 1(63).

Swianiewicz P., 2000, W posqukiwaniu optymalnej wielkości Opinie burmistrzón z Europy Środkowej na temat taczenia lub dzielenia rzqdzonych przez nich gmin, „Studia Regionalne i Lokalne", nr 2(2).

Swianiewicz P., 2009, Reformy konsolidacji terytorialnej - teoria i praktyka krajów Europy Środkowo-Wschodniej, „Samorząd Terytorialny”, nr 4.

Szarfenber R., 2016, Remunicypalizacja (rekomunalizacja) ustug publicznych, http://rszarf. ips.uw.edu.pl/pdf/remunicypalizacja.pdf.

Sztando A., 2017, Lokalistyczne cechy zarzadzania strategicznego rozwojem lokalnym, „Prace Naukowe Uniwersytetu Ekonomicznego we Wrocławiu" Gospodarka lokalna $i$ regionalna $w$ teorii i praktyce, $\mathrm{nr} 477$.

Tiebout Ch. M., 1956, A Pure Theory of Local Expenditures, "Journal of Political Economy", 64(5).

Wilkin J., 2005, Teoria uyboru publicznego - bomo oeconomicus w sferze polityki, [w:] Teoria wyboru publicznego. W step do ekonomicznej analizy polityki $i$ funkejonowania sfery publicznej, J. Wilkin (red.), Wydawnictwo Naukowe Scholar, Warszawa.

Wilkin J. (red.), 2012, Teoria wyboru publicznego. Główne nurty $i$ zastosowania, Wydawnictwo Naukowe Scholar, Warszawa.

Wnuk-Lipiński E., 2008, Socjologia ṡycia publicznego, Wydawnictwo Naukowe Scholar, Warszawa. 